\title{
Effects of piperitenone oxide on the intestinal smooth muscle of the guinea pig
}

\author{
P.J.C. Sousa, \\ P.J.C. Magalhães, \\ C.C. Lima, V.S. Oliveira \\ and J.H. Leal-Cardoso
}

Departamento de Fisiologia e Farmacologia, Centro de Ciências da Saúde, Universidade Federal do Ceará, 60430-270 Fortaleza, CE, Brasil

\section{Correspondence \\ J.H. Leal-Cardoso \\ Departamento de Fisiologia \\ e Farmacologia, CCS, UFC \\ Rua Coronel Nunes de Melo, 1127 \\ 60430-270 Fortaleza, CE \\ Brasil \\ Fax: 55 (085) 243-9333}

Research supported by CNPq, FINEP, FUNCAP and Colégio

Christus. J.H. Leal-Cardoso is

a Visiting Professor of the

Fundação Universidade Estadual

do Ceará.

\begin{abstract}
We investigated the effects of piperitenone oxide (PO), a major constituent of the essential oil of Mentha x villosa, on the guinea pig ileum. PO (30 to $740 \mu \mathrm{g} / \mathrm{ml}$ ) relaxed basal tonus without significantly alterating the resting membrane potential. In addition, $\mathrm{PO}$ relaxed preparations precontracted with either $60 \mathrm{mM} \mathrm{K}^{+}$or $5 \mathrm{mM}$ tetraethylammonium in a concentration-dependent manner. At concentrations from 0.1 to $10 \mu \mathrm{g} / \mathrm{ml}$ PO potentiated acetylcholine-induced contractions, while higher concentrations ( $>30 \mu \mathrm{g} / \mathrm{ml}$ ) blocked this response. These higher PO concentrations also inhibited contractions induced by $60 \mathrm{mM} \mathrm{K}^{+}$. PO also blocked the components of acetylcholine contraction which are not sensitive to nifedipine or to solutions with nominal zero $\mathrm{Ca}^{2+}$ and EGTA. These results show that $\mathrm{PO}$ is a relaxant of intestinal smooth muscle and suggest that this activity may be mediated at least in part by an intracellular effect.
\end{abstract}

Piperitenone oxide (PO; a monoterpenoid ketone) is an important chemical constituent of the essential oil of many Mentha species such as Mentha longifolia, $M$. rotundifolia, M. suaveolens, M. spicata L., and M. x villosa (1). Some Mentha species are widely employed in folk medicine as ansiolytics and to treat digestive problems and diarrhea with blood in the stools, as is the case for Mentha villosa in northeastern Brazil (2). Mentha $x$ villosa has been shown to exhibit antiparasitic actions in amebiasis, giardiasis and urogenital trichomoniasis (3-5) and has been exploited by the local phytotherapeutic industry under the name Mentha crispa. Studies on the identification of its active principle
Key words

- Piperitenone oxide

- Mentha x villosa

- Ileum

- Essential oil

- Muscle relaxation

- Acetylcholine

- $\mathrm{K}^{+}$-induced contraction have reported activity of the essential oil $(6,7)$ of Mentha x villosa (EOMV), indicating the high content of $\mathrm{PO}$, in addition to 23 other minor constituents (8-10). The widespread use of Mentha $x$ villosa has stimulated pharmacological studies on extracts of this plant and its constituents.

Since in a preliminary study we found that PO was active on skeletal muscle (11), we decided to investigate whether this substance is active on smooth muscle. Our data indicated that PO relaxes intestinal smooth muscle by a mechanism that may involve an intracellular action on smooth muscle fibers.

Male guinea pigs (200 to $300 \mathrm{~g}$ ) were sacrificed by a blow to the base of the skull 
and 2-cm pieces of the ileum were dissected from the ileum segment 10 to $20 \mathrm{~cm}$ proximal to the ileocecal valve. The material was allowed to equilibrate for $1-2 \mathrm{~h}$ in $10-\mathrm{ml}$ chambers containing Tyrode solution (composition: $136 \mathrm{mM} \mathrm{NaCl}, 2.6 \mathrm{mM} \mathrm{KCl}, 0.98$ $\mathrm{mM} \mathrm{MgCl}_{2}, 2.0 \mathrm{mM} \mathrm{CaCl} 2,0.36 \mathrm{mM}$ $\mathrm{NaH}_{2} \mathrm{PO}_{4}, 11.9 \mathrm{mM} \mathrm{NaHCO}$, and $5.5 \mathrm{mM}$ glucose), $\mathrm{pH} 7.4$, maintained at $37^{\circ} \mathrm{C}$, and bubbled with air. In solutions with elevated potassium levels, $\mathrm{NaCl}$ was simultaneously decreased to maintain osmolarity. Acetylcholine (ACh), tetraethylammonium (TEA) and PO solutions were prepared by adding the substance directly to the Tyrode solution. All reagents used in this study were analytical grade, and purchased from Sigma Chemical, Merck, or Reagen. PO (molecular weight 166.099) (12) was isolated (13) and kindly provided by the Laboratório de Produtos Naturais of the Universidade Federal do Ceará. PO isolation was a by-product of the isolation of the EOMV (13). Briefly, steam was percolated through freshly chopped plant leaves and collected into a glass condenser. Upon separation of the essential oil from the condensed water, the water phase contained pure PO (as determined by gas chromatography and mass spectrometry, GC/MS) due to the relatively high water solubility of $\mathrm{PO}$ compared with other EOMV constituents. PO was recovered from water with dichloromethane and purified by evaporation of dichloromethane. The absence of dichloromethane was confirmed by $\mathrm{GC} /$ MS analysis. When $\mathrm{K}^{+}$was used as the contraction stimulus (potassium contraction) a nutrient solution containing $60 \mathrm{mM} \mathrm{K}^{+}$was substituted for 2 to $3 \mathrm{~s}$ for the normal Tyrode solution. The contractile amplitude measured was the peak deflection. Mechanical responses were recorded with an isotonic lever and a kymograph.

Transmembrane electric potentials were measured with micropipettes (50-100 $\mathrm{M} \Omega$ tip resistance) filled with $3 \mathrm{M} \mathrm{KCl}$ and connected by a silver chloride wire to the input of an electrometer (W.P. Instruments Inc., model M4-A, New Haven, CT) and monitored on an oscilloscope (Tektronix, model 5111A, Beavertan, OR). At least ten cells were randomly impaled in each preparation, five in the presence of $\mathrm{PO}$ and five were used as control. In cells with the transmembrane potential oscillating rhythmically, the peak negative voltage was recorded.

The results are reported as mean \pm SEM, with the number of experiments given in parentheses. Differences were considered to be significant when $\mathrm{P} \leq 0.05$. The $\mathrm{EC}_{50}$ and $\mathrm{IC}_{50}$ values were calculated by interpolation from semi-logarithmic plots.

PO (30 to $740 \mu \mathrm{g} / \mathrm{ml})$ elicited a progressively increasing relaxation of the ileum $\left(\mathrm{EC}_{50}: 79.7 \pm 17.4 \mu \mathrm{g} / \mathrm{ml}, \mathrm{N}=14\right)$, with the maximal effect corresponding to $13.5 \pm 3.0 \%$ of the amplitude of contraction induced by $60 \mathrm{mM} \mathrm{K}^{+}$(Figure 1A,B) and was reversible upon $\mathrm{PO}$ removal in all cases. Preparations precontracted with $60 \mathrm{mM} \mathrm{K}^{+}$or $5 \mathrm{mM}$ TEA were relaxed by piperitenone oxide (30 to $330 \mu \mathrm{g} / \mathrm{ml}$ ) in a concentration-dependent manner, with $\mathrm{IC}_{50}$ values of $150.8 \pm 16.3(\mathrm{~N}$ $=8)$ and $200.8 \pm 21.5 \mu \mathrm{g} / \mathrm{ml}(\mathrm{N}=10)$, respectively (Figure 1C). This relaxant effect of $\mathrm{PO}$ in the presence of $60 \mathrm{mM} \mathrm{K}$, when all neuronal action potentials are blocked by inactivation of the fast sodium channels (14), strongly argues against the involvement of a nervous mechanism in the action of piperitenone oxide. Moreover, this effect at $60 \mathrm{mM} \mathrm{K}^{+}$also indicates that the smooth muscle relaxant action of PO is not mediated by the opening of membrane $\mathrm{K}^{+}$ channels.

The transmembrane potential of ileal smooth muscle was not affected by PO in normal Tyrode solution $\left(5 \mathrm{mM} \mathrm{K}^{+}\right)$; the mean values were $-56.4 \pm 1.0 \mathrm{mV}(\mathrm{N}=17)$ and $-50.7 \pm 0.9 \mathrm{mV}(\mathrm{N}=23)$ in the absence and presence of PO $(100 \mu \mathrm{g} / \mathrm{ml})$, respectively. However, in the presence of $60 \mathrm{mM} \mathrm{K}^{+}$the membrane potential was significantly more negative in the presence of PO $(100 \mu \mathrm{g} / \mathrm{ml})$ : 
$-25.1 \pm 0.8 \mathrm{mV}(\mathrm{N}=25)$ compared to the mean control value of $-21.0 \pm 0.5 \mathrm{mV}(\mathrm{N}=$ 24). This difference, however, is too small to explain any smooth muscle relaxant effect of PO.

PO potentiated the ACh-induced contraction in a concentration range of 0.1 to 10 $\mu \mathrm{g} / \mathrm{ml}$. PO also blocked the contractions induced by ACh (applied at concentrations causing a submaximal effect) and by $60 \mathrm{mM}$ $\mathrm{K}^{+}$(Figure 1D), with $\mathrm{IC}_{50}$ values of $97.9 \pm$ $14.4 \mu \mathrm{g} / \mathrm{ml}(\mathrm{N}=9)$, and $61.7 \pm 13.8 \mu \mathrm{g} / \mathrm{ml}(\mathrm{N}$ $=6)$, respectively. These values were not significantly different, suggesting that the inhibitory effect of PO is nonspecific and is not a selective effect on neurotransmitter action. The potentiation of the ACh-induced contraction shows that $\mathrm{PO}$ appears to exert additional effects at low doses $(0.1 \mu \mathrm{g} / \mathrm{ml}$ PO $=602 \mathrm{nM}$ ), suggesting multiple mechanisms of action.

The effect of PO on the component of ACh-induced contraction which was not blocked by a concentration of nifedipine sufficient to fully block the $\mathrm{K}^{+}$-induced contraction is shown in Figure 2A. PO reduced
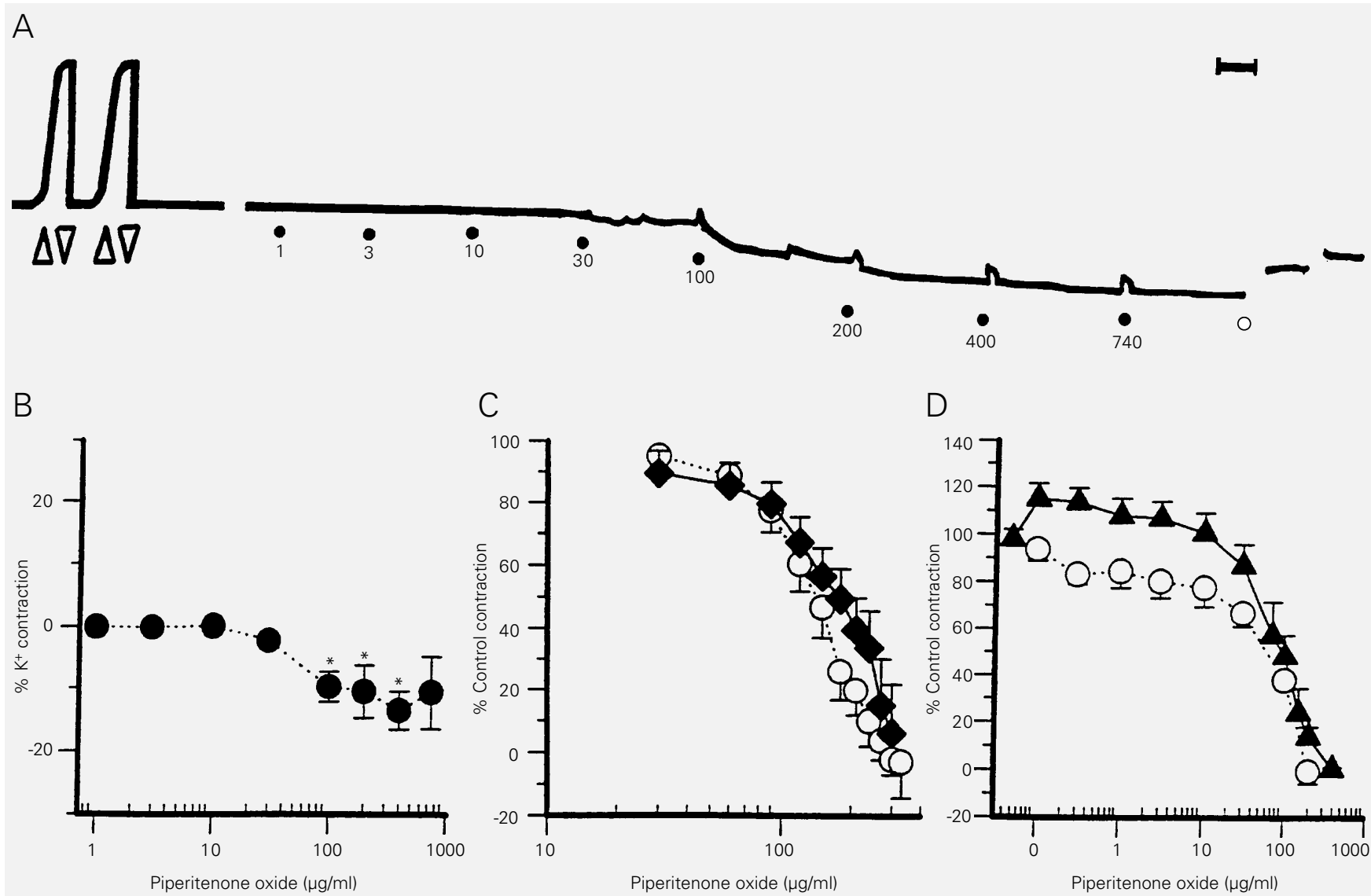

Figure 1 - Effect of piperitenone oxide on spontaneous tonus and contractions induced by $60 \mathrm{mM} \mathrm{K} \mathrm{K}^{+}$, tetraethylammonium (TEA) and acetylcholine (ACh). A, Kymograph recording showing relaxation of the spontaneous muscle tonus induced by increasing concentrations of piperitenone oxide. Filled circles show the moment of application of (from left to right) 1, 3, 10, 30, 100, 200, 400 and $740 \mu \mathrm{g} / \mathrm{ml}$ piperitenone oxide. Open circle indicates the wash step. Line interruption, 25 min with kymograph stopped. On the left, two contractions induced by $60 \mathrm{mM} \mathrm{K}^{+}$( $\mathrm{K}^{+}$contraction) are shown. Note the recovery of spontaneous tonus after washing piperitenone oxide. $B$, Graph showing the quantification of the relaxation of the spontaneous tonus induced by piperitenone oxide. $C$, Graph showing piperitenone oxide-induced relaxation of muscles contracted in the presence of $60 \mathrm{mM} \mathrm{K}^{+}$(open circles) and TEA (5 mM, filled lozenges). Ordinate, contraction amplitude as percentage of the contraction before application of piperitenone oxide. $D$, Graph showing piperitenone oxide-induced blockade of $\mathrm{K}^{+}$contraction (open circles) and concentrations of ACh for the submaximal response (filled triangles). Ordinate, same as in $C .{ }^{*} \mathrm{P}<0.05$ compared to control (Dunn's test). 
Figure 2 - Effect of piperitenone oxide (PO) on the components of acetylcholine (Ach) contraction which is not blocked by nifedipine (Nif) or EGTA and $\mathrm{Ca}^{2+}$ removal from the bath solution. $A$ and $B$, Kymograph recording showing a typical experiment in which piperitenone oxide blocked the contraction promoted by ACh in the presence of nifedipine (A) or of EGTA and after $\mathrm{Ca}^{2}+$ removal from the nutrient solution (B). The nifedipine concentration $(0.3 \mu \mathrm{g} / \mathrm{ml})$ was enough to completely block the contraction induced by $60 \mathrm{mM}$ $\mathrm{K}^{+} . \mathrm{K}^{+}, 60 \mathrm{mM}$; Ach, $60 \mu \mathrm{M}$ in $\mathrm{A}$ and $B ; \mathrm{PO}, 200 \mu \mathrm{g} / \mathrm{ml}$; EGTA, $0.2 \mathrm{mM}$. Horizontal bars above the recording indicate when the preparation was exposed to the substance or ionic species; the kymograph was stopped during the application of EGTA or nifedipine and during the first four subsequent minutes. Same horizontal calibration for all tracings (1 $\mathrm{min}$ ).

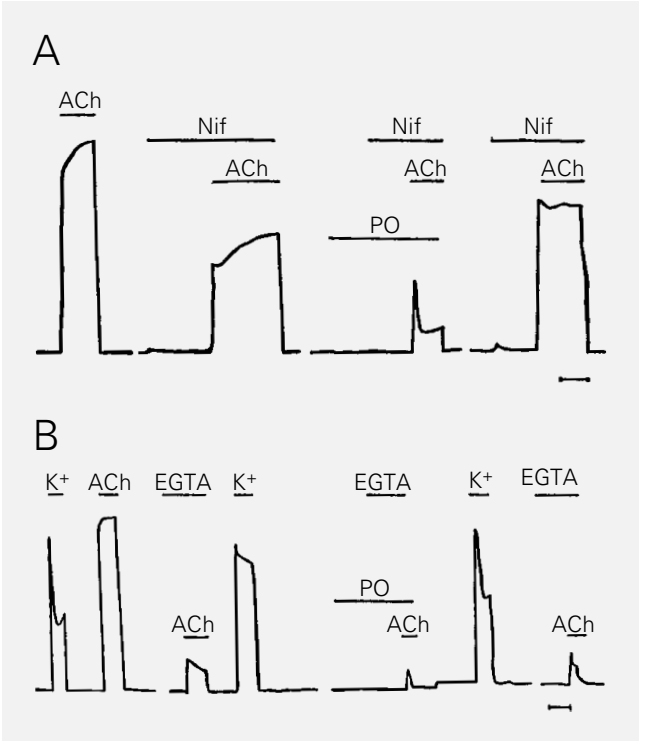

the amplitude of this nifedipine-insensitive component, which did not depend on $\mathrm{Ca}^{2+}$ influx through voltage-dependent $\mathrm{Ca}^{2+}$ channels, to $36.6 \pm 10.8 \%(\mathrm{~N}=10)$ of control values. The effect of PO on the component of the ACh-induced contractile response which was not due to extracellular $\mathrm{Ca}^{2+}$ entry was studied using the protocol illustrated in Figure 2B. PO reversibly reduced the amplitude of the first contraction induced by ACh in $\mathrm{Ca}^{2+}$-free nutrient solutions (absence of $\mathrm{Ca}^{2+}$ and presence of $0.2 \mathrm{mM}$ EGTA) to 43.1 $\pm 7.8 \%(\mathrm{~N}=4)$ of control values.

The main conclusion of the present study is that piperitenone oxide has a relaxant, depressant activity on intestinal smooth muscle. This effect is likely to be caused, at least partially, by an intracellular inhibitory action on smooth muscle since 1) it occurred in the presence of $60 \mathrm{mM} \mathrm{K}^{+}$, a situation in which action potentials are unlikely to occur due to inactivation of the fast sodium channel, 2) it did not depend on the plasmalemmal membrane mechanisms investigated, i.e., alteration of transmembrane potential, opening of $\mathrm{K}^{+}$channels, and closure of voltagedependent $\mathrm{Ca}^{2+}$ channels, and 3) it blocked both the extracellular and intracellular components of Ach contraction.

Therefore, the present data suggest that PO, an important constituent of the extract of many Mentha species, is a nonspecific depressant of intestinal smooth muscle. Further experiments are required to elucidate the mechanism of action of PO.

\section{Acknowledgments}

We would like to thank Dr. David N. Criddle for discussion and assistance in preparing the manuscript, Dr. F.J.A. Matos, Dr. M.I.L. Machado and Dr. S.H. Matos, Laboratório de Produtos Naturais, UFC, for encouragement and for kindly providing us with PO, Mr. L.C.S. Oliveira and Mr. L.A.P. Andrade for help in some experiments, and Mr. Evanir Gonçalves for technical assistance. 


\section{References}

1. Lawrence BM (1992). Chemical components of Labiatae oils and their exploitation. In: Harley RM \& Reynolds T (Editors), Advances in Labiate Sciences. Royal Botanic Gardens, Kew, 399-436.

2. Matos FJA (1994). Farmácias Vivas. 2nd edn. Edições UFC, Fortaleza, CE.

3. Borba MOP, Kobayashi S, Aca EB \& Medeiros FP (1990). Frações ativas de Mentha crispa sobre cultura de Entamoeba histolytica - cepa saw 1627 (Parte II). XI Simpósio de Plantas Medicinais do Brasil, 4.69 (Abstract).

4. Melo AM, Pinho S, Santana CF, Santos ER \& Souza IA (1992). Primeiras observações sobre o uso da Menta crispa em tricomoníase uro-genital. XII Simpósio de Plantas Medicinais do Brasil, 160 (Abstract).

5. Santana CF, Almeida ER, Dos Santos R \& Souza IA (1992). Actions of Mentha crispa hydroethanolic extract in patients bearing intestinal protozoan. Fitoterapia, 63: 409410.
6. Almeida RN \& Barbosa-Filho JM (1994). Avaliação do efeito antinociceptivo do óleo essencial e da Rotundifolona obtidos de Mentha x villosa Hudson. Abstracts of the IX Reunião Anual da Federação de Sociedades de Biologia Experimental, 194.

7. Lima CAH, Almeida RN, Barbosa-Filho JM \& Thomas G (1994). Efeitos farmacológicos do óleo essencial da Mentha x villosa Hudson sobre o sistema nervoso central. Abstracts of the IX Reunião Anual da Federação de Sociedades de Biologia Experimental, 202.

8. Craveiro AA, Alencar JW, Matos FJA, Machado MIL \& Monte FJO (1990). Novos óleos essenciais de Labiadas do Nordeste. XI Meeting of Sociedade Brasileira de Química, Caxambu, MG.

9. Hiruma CA (1993). Estudo químico e farmacológico do óleo essencial das folhas de Mentha x villosa Hudson. Doctoral thesis, Universidade Federal da Paraíba.
10. Hiruma CA, Almeida RN \& Barbosa-Filho JM (1992). Óleo essencial de Mentha $x$ villosa Huds com atividade sobre o sistema nervoso central. XII Simpósio de Plantas Medicinais do Brasil, 073 (Abstract).

11. Cavalcante ADA, Serpa AKL, Soares FP, Leal-Cardoso JH \& Fogaça RTH (1995). Efeitos do óleo essencial da Mentha $x$ villosa Huds em músculo esquelético de sapo. Abstracts of the XIV Encontro Universitário de Iniciação à Pesquisa da Universidade Federal do Ceará, 65 (231), Fortaleza, CE.

12. Buckingham J (1994). Dictionary of Natural Products. Vol. 2. Chapman and Hall, London, 2169.

13. Craveiro AA, Matos FJA \& Alencar JW (1976). A simple and inexpensive steam generator for essential oil extraction. Journal of Chemical Education, 53: 562.

14. Hodgkin AL \& Huxley AFA (1952). Quantitative description of membrane current and its application to conduction and excitation in nerve. Journal of Physiology, 117: 500-544. 